Egyptian J. of Nutrition Vol. XXXIV No. 3 (2019)

\title{
Potential Effect of Sour Orange Peel (Citrus Aurantium) Supplementation on Lipid Profile and Liver Function of Albino Rats Fed on High Fat Diet
}

\author{
Samar, K.H. *; Seham A.M. Tharwat ${ }^{* *}$ \\ andAshraf A. Abdel Megeid ${ }^{\star *}$ \\ * Graduate student, Nutrition and Food Science Department, Faculty \\ of Home Economics, Helwan University - Egypt \\ ${ }^{* *}$ Department of Nutrition and Food Science, Faculty of Home \\ Economics,HelwanUniversity - Egypt.
}

\section{Abstract}

The present study was carried out to investigate the effects of supplemented high fat diet (HFD) with two levels (1.5 and $3 \%$ ) from dried unripe or ripe sour orange peel on serum leptin, glucose, lipid profile and liver functionsof albino rats. A total of 36 male albino rats weighing $(40 \pm 5 \mathrm{~g})$ were used.The rats were divided into two main groups. The first main group $(n=6)$ fed on basal diet (BD) and used as a negative control group (-ve). The second main group 30 rats fed on high fat diet (HFD) and divided into five subgroup. The first subgroup fed on (HFD) all over the experimental period and used as a positive control group (+ve). The other (4subgroups) were fed or (HFD) supplemented with two levels (1.5 or $3 \%$ ) from dried unripe sour orange peel (DURSOP) or dried ripe sour orange peel (DRSOP) for 8 weeks. At the end of experiment, rats were sacrificed and blood samples were collected, then serum was separated, glucose, 


\section{Samar, K.H.; Seham A.M. Tharwat \\ and Ashraf A. Abdel Megeid}

leptinlevel, lipid profile as well as AST, ALT and ALP enzymes were determined. The obtained results revealed that feeding 25 days of age albino rats on (HFD) supplemented with (3\% from DURSOP or DRSOP) induced a significantdecrease in serum leptin, glucose, total cholesterol (TC), triglycerides (TG), LDL-C, VLDL-C, AST, ALT and $A L P$, on the other hand significant increase in serum HDLcoccurredin albino rats fed on HFD supplemented with (3\%) from (DURSOP) or (DRSOP) followed by group fed on (HFD) supplemented with (1.5\%). In conclusion,the results showed that administration of citrus unripe or ripe sour orange peel at levels (3 or $1.5 \%$ ) to rats fed on (HFD) could assist in management of obesity and its complications.

\section{Introduction}

Over weight and obesity are the fifth leading risk for global death. At least 2.8 million adults die each year as a result of being overweightor obese. In addition, $44 \%$ of the diabetes burden, $23 \%$ of the ischemic heart disease and between 7 and $41 \%$ of certain cancer burdens are attributable to overweight and obesity (WHO, 2012). In developing countries with emerging economics (Classified by the world Bank as lower and middle -income countries), the rate of increase of childhood, overweight and obesity has been more than $30 \%$ higher than that developed countries (WHO, 2015). 
Egyptian J. of Nutrition Vol. XXXIV No. 3 (2019)

Obesity is a significant and increasing public health problem worldwide. Even through there are several treatments, such as surgery and drugs, there seems to be no efficient treatment without potential side effects., thus considering a life style modification as the best option. In addition to a lifestyle modification, natural alternatives may provide increased health expectancy. Several plants possess anti-obesity potential and have been poorlystudied, while others are not even promoted (Claudia et al., 2015).

Polymethoxy flavones the major components of orange peel have been found to have health benefits including anti-inflammatory, anti-carcinogenic, anti-viral anti-oxidant, anti-thrombogenic and antiatherogenic properties (Li et al., 2009). Therefore, the present study was carried out to investigate the effects of supplemented HFD with (DURSOP) or (DRSOP) on serum leptin, glucose, lipid profile and liver enzymes of albino rats.

\section{Material and methods}

\section{Materials}

Sour orange (Citrus aurantium) were obtained from El Abour market. The raw orange ripe and unripe were washed carefully and peel cut into small pieces to be exposed to solar energy at national research center and ground to fine powder.

\section{Chemicals}

Casein, vitamins,minerals, cellulose, choline chloride were obtained from Elgomhoria Company, Cairo, Egypt. 


\section{Samar, K.H.; Seham A.M. Tharwat \\ and Ashraf A. Abdel Megeid}

Kits for biochemical analysis were obtained from Gamma trade Cofor Pharmaceutical and chemicals. Dokki, Egypt.

\section{Rats}

Thirty-six male albino rats of Sprague Dawleystrain 25 days age $(40 \pm 5 \mathrm{~g}$ b.wt) were obtained from the laboratory of animal's colony, ministry of health and population, Helwan, Cairo, Egypt.

\section{Experimental animalsDesign}

Rats were housed in individual cages under hygienic laboratory conditions and were fed on basal diet adlibitum for one week for adaptation in the animal house of faculty of Home Economics, HelwanUniversity. The basal diet in the preliminaryexperiment consists of $14 \%$ casein (protein> $85 \%$ ), corn oil $4 \%$, salt mixture $3.5 \%$, vitamins mixture $1 \%$, choline chloride $0.25 \%$, cellulose $5 \%$ and $(72.25 \%$ ) corn starch. Reeves et al., (1993).

The salt mixture and vitamin mixture were prepared according to Hegested et al., (1941) and Campbell (1963). After a period of adaptation on basal diet, rats were divided into two main groups.The first main group (6 rats) fed on basal diet (negative group). The second main group: thirty rats were fed on high fat diet (HFD) all over the experimental period containing (14\% protein from casein, $20 \%$ fat "19\% saturated fat and $1 \%$ unsaturated fat", $5 \%$ cellulose, $3.5 \%$ salt mixture, $1 \%$ vitamin mixture, $10 \%$ sucrose , $0.25 \%$ choleinchloride and the remainder is cornstarch). Supplementation of diet with dried unripe or ripe dried peel of sour orange was at the expense of starch. Rats of the second main group were divided into five subgroups. one of them 6 rats was fed on (HFD) used as a positive control group and the other four subgroups were fed on (HFD) containing $1.5 \%$ 
Egyptian J. of Nutrition Vol. XXXIV No. 3 (2019)

dried unripe peel (DURSOP), 3\% (DURSOP), 1.5\% dried ripe peel DRSOP and $3 \%$ DRSOP, respectively.During the experimental period body weight and food consumption were measured twice a week and total feed intake of the experimental period (8weeks) and body weight gain \% were calculated.

\section{Biochemical analysis of serum}

At the end of the experiment period, the rats were starved for $12 \mathrm{~h}$ and then sacrificed under ether anaesthetized. Blood samples were collected from hepatic portal vein by the means of fine capillary glass tubes Schermer, (1967). Blood samples were received into clean dry centrifuge tube and left to clot at room temperature, then centrifuged for 10 minutes at 3000 r.p.m.to separate serum. Serum was careful separated into dry clean Wasserman tubes, using a Pasteur pipette and kept frozen at $\left(-20^{\circ} \mathrm{C}\right)$ till estimation of some biochemical parameters.Serum samples used for determination of total cholesterol (Allain et al., 1974), triglycerides (Foster and Dumns., 1973), high density lipoprotein cholesterol HDL-C (LopesVirliaet al., 1977).While serum low- density lipoprotein cholesterol (LDL-C) and very low-densitylipoproteincholesterol (VLDL-C) were calculated according to theequation of Friedwald et al., (1972). Serum Aspartate Amino Transferase(AST) and Alaine Amino Transferase $(\mathrm{ALT}) \quad$ (Reitman and Frankel, 1957)andAlkalinephosphatase (ALP)(Belfield and Goldberg, 1971). Statistical analysis:was carried out using SPSS statistical software version 11 (SAS., 2004). 


\section{Samar, K.H.; Seham A.M. Tharwat \\ and Ashraf A. Abdel Megeid}

\section{Results and Discussion}

Effect of sour orange peel(citrus aurantium) on lipid profile of Albino Rats fed on high fat diet

Table (1\&2) Shows the effect of high fat diet (HFD) supplemented with two levels (1.5 or $3 \%$ ) from dried unripe sour orange peel (DURSOP) or dried ripe sour orange peel (DRSOP) on serum total cholesterol (TC), triglyceride (TG), low-density lipoprotein cholesterol (LDL-C), very low densitylipoprotein cholesterol (VLDL-C) and high density lipoprotein cholesterol (HDL-C) in albino rats 25 days of age fed on (HFD). The mean values of serum total cholesterol and triglycerides significantly $(P<0.05)$ increased for positive control group, while the mean values of $(H D L-c)$ significantly decreased $(P<0.05)$, the mean values of $($ LDL-C) and (VLDL$C)$ recorded significantly increased $(P<0.05)$ in the control positive group (fed on high fat diet), as compared to the negative control (fed on BD). In this respect Wu et al., (2013)reported that (HFD) induced increased serum (TG) and (TC) levels compared to those fedon the (LFD).

Our results revealed that all animals groups which fed on (HFD) supplemented with (1.5 or $3 \%$ ) from (DURSOP or DRSOP), recorded a significant decrease $(P<0.05)$ in $(T C)$, as compared to the (+ve) control group.Results showed a significant difference between the (-ve) control group and animal group fed on(HFD) supplemented 
Egyptian J. of Nutrition Vol. XXXIV No. 3 (2019)

with (3\%)from (DURSOP) or (DRSOP) followed by groups fed on (HFD) supplemented with (1.5\%) from (DRSOP).

Concerning the (TG) results revealed that groups fed on (HFD) supplemented with (1.5 or $3 \%$ ) from (DURSOP or DRSOP) recorded significantly decrease $(P<0.05)$ in $(T G)$ levels. The best results was recorded by group fed on (HFD) supplemented with (3\%) from (DRSOP) followed by (3\%) from (DURSOP).

The phenolic and flavonoids compounds extracted from (DURSOP and DRSOP) it could be identify 18 fraction, characterizes with high amounts of Naringin, Hespirdin ,Apig 6 rhamnose 8glucose, Rutin and Quercetrin to be the predominant compounds. Concerning phenolic compounds resulted in 19 fraction, while (DRSOP) showed 21 fraction. The predominant phenolic in (DRSOP) was pyrogallol, whichamounted 9456.49 vs 3541.46 in (DURSOP).The predominant phenolic in (DURSOP), isoFerulic, Benzoic,Ferulic, catechein, P-OH-benzoic, caffeine and 3.4, 5 methoxy-cinnamic. Therefore, our results revealed that Egyptian sour orange peel have considerable number of healthy compounds namely polyphenols and flavonoids. Biological results also showed that the supplementation of (HFD) with (DURSOP or DRSOP) at levels ( 3 or $1.5 \%$ ) induced a significant reduction in body weight gain $\%$, organs weight /body weight and peritoneal fat pad \%.

In this respect, lee et al., (2015) reported that citrus peel has a potential benefit in preventing obesity through the inhibition of 


\section{Samar, K.H.; Seham A.M. Tharwat \\ and Ashraf A. Abdel Megeid}

lipogenesis and adipogenesis, Lee suggested that the B-oxidation related genes were increased in rats fed combination composed of citrus unshiu peel extracts compared to that of animal fed on (HFD).

In this concern kelleya et al., (2013) reported that citrus flavonoids have positive effects against obesity such as lower in LDL$C$ and (TG). Citrus peel treatment reduced body weight gain and decreasedepididymal fat, mesenteric fat, plasma and hepatic (TG) levels(Karagozlu et al., 2016).

Concerning serum lipoprotein cholesterol resultpresented in table (2) showed the effect of (HFD) supplemented with (1.5 or $3 \%$ ) from (DURSOP or DRSOP) on serum lipoprotein cholesterol fraction of 25 days albino rats. Our results revealed that all animal groups fed on (HFD) supplemented with 1.5 or $3 \%$ from (DURSOP or DRSOP) showed a significant decrease in LDL-C and VLDL-C, as compared to control (+ve) fed on(HFD). The best results recorded bysupplementation of (3\%) from (DRSOP or DURSOP). On the other hand result showed that all groups fed on (HFD) supplemented with (1.5 or $3 \%$ ) from (DURSOP or DRSOP) recorded a significant increase $(P<0.05)$ in $\mathrm{HDL}-\mathrm{C}$ level, while $(+\mathrm{ve})$ control fed on (HFD) recorded a significant decrease $(P<0.05)$ in HDL-C.

It is known that there is a correlation between lipoprotein cholesterol changes and obesity. In obesity HDL-clevel and elevation 
Egyptian J. of Nutrition Vol. XXXIV No. 3 (2019)

of HDL-C is one of the targets for ant-obesity treatment (Vozarova et al., 2002).

Effect of sour orange peel (Citrus aurantium) on serum glucose, leptin and liver functions in albino rats fed on high fat diet

Table (3) illustrate the effect of two levels (1.5 or $3 \%$ ) from (DURSOP or DRSOP) on serumglucose, leptin, aspartate amino transferase (AST), alanine amino transferase(ALT) and alkalainphosphatase (ALP) levels in serum rats fed on (HFD). The results revealed that the mean values of serum glucose, leptin, AST, ALT and ALP levels for (+ve) control group fed on (HFD) showed highly significant increase $(P<0.05)$, as compared to the negative control group $(139.293 \pm 5.320 \mathrm{mg} / \mathrm{dl}, \quad 17.925 \pm 1.474 \mathrm{ng} / \mathrm{ml}$, $148.423 \pm 5.678 \mathrm{u} / \mathrm{l}, 78.476 \pm 2.392 \mathrm{u} / \mathrm{l}$ and $168.487 \pm 4.752 \mathrm{u} / \mathrm{l}$, vs. $77.830 \pm 4.508 \mathrm{mg} / \mathrm{dl}, \quad 5.986 \pm 0.297 \mathrm{ng} / \mathrm{ml}, \quad 53.884 \pm 2.749 \quad \mathrm{u} / \mathrm{l}$, $20.598 \pm 2.035 \mathrm{u} / \mathrm{l}$ and $86.967 \pm 1.966 \mathrm{u} / \mathrm{l}$, respectively).

Animal groups fed on (HFD) supplemented with (1.5 or $3 \%$ ) from (DURSOP or DRSOP) recorded a significant decrease $(P<0.05)$ in serum levels of glucose, leptin, AST, ALT and ALP, as compared to the (+ve) control group. The best results recoded by groups fed on (HFD) supplemented with $3 \%$ from (DRSOP).

In this respect (Alam et al., 2014) reported that naringin prevented the increase in hepatic marker enzymes activities (AST, ALT and ALP) and reduced the accumulation of lipid deposition and fibrosis in the liver of high carbohydrate, high fat diet fed obese rats. Naringin supplementation also improved the mitochondrial respiration in these rats, suggesting an improvement in mitochondrial compartment dysfunction and lipid energy expenditure by liver. 


\section{Samar, K.H.; Seham A.M. Tharwat}

\section{and Ashraf A. Abdel Megeid}

In conclusion the results taken together indicated that the dried Egyptian sour orange peel (citrus aurantium) as a good sources of phenols and flavonoids incorporate into (HFD) could contribute to potential management of obesity, being beneficial to alleviate the complications present in obesity. 
Egyptian J. of Nutrition Vol. XXXIV No. 3 (2019)

Table (1): Effect of high fat diet supplemented with dried unripe or ripe sour orange peel on serum total cholesterol and triglycerides of 25 days albino rats:

\begin{tabular}{|c|c|c|c|}
\hline \multicolumn{2}{|c|}{$\begin{array}{ll}\text { Groups } & \text { parameter } \\
\end{array}$} & $\begin{array}{l}\text { Cholesterol } \\
\mathrm{mg} / \mathrm{dl}\end{array}$ & $\begin{array}{c}\text { Triglycerides } \\
\mathrm{mg} / \mathrm{dl}\end{array}$ \\
\hline \multirow{2}{*}{\multicolumn{2}{|c|}{ Control (-ve) group fed on (BD) }} & $79.574^{\mathrm{e}}$ & $39.058^{\dagger}$ \\
\hline & & \pm 3.224 & \pm 3.359 \\
\hline \multirow{2}{*}{\multicolumn{2}{|c|}{ Control (+ve) group fed on (HFD) }} & $150.585^{a}$ & $79.933^{\mathrm{a}}$ \\
\hline & & \pm 6.577 & \pm 2.600 \\
\hline \multirow{8}{*}{ 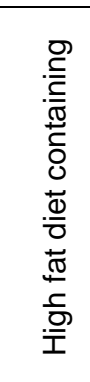 } & $1.5 \%$ dried un ripe peel & $138.971^{b}$ & $70.915^{b}$ \\
\hline & (DURSOP) & \pm 6.891 & \pm 4.024 \\
\hline & $3 \%$ dried un ripe peel & $125.005^{c}$ & $61.583^{d}$ \\
\hline & (DURSOP) & \pm 2.351 & \pm 2.467 \\
\hline & \multirow{2}{*}{$1.5 \%$ dried rip peel (DRSOP) } & $130.017^{c}$ & $66.255^{c}$ \\
\hline & & \pm 3.673 & \pm 4.322 \\
\hline & \multirow{2}{*}{$3 \%$ dried ripe peel (DRSOP) } & $116.540^{d}$ & $57.162^{\mathrm{e}}$ \\
\hline & & \pm 2.685 & \pm 2.889 \\
\hline
\end{tabular}

Values are expressed as means \pm SD.

Values at the same column with different letters are significant at $\mathrm{P}<0.05$. 


\section{Samar, K.H.; Seham A.M. Tharwat}

\section{and Ashraf A. Abdel Megeid}

Table (2): Effect of high fat diet supplemented with dried unripe or ripe sour orange peel or serum lipoproteins cholesterol fractions of 25 days albino rats:

\begin{tabular}{|c|c|c|c|c|}
\hline \multicolumn{2}{|c|}{$\begin{array}{ll}\text { Groups } & \text { parameter }\end{array}$} & HDL-c mg/dl & LDL-c mg/dl & VLDL-c mg/dl \\
\hline \multicolumn{2}{|c|}{ Control (-ve) group } & $\begin{array}{l}44.755^{\mathrm{a}} \\
\pm 3.091\end{array}$ & $\begin{array}{l}27.008^{f} \\
\pm 1.213\end{array}$ & $\begin{array}{r}7.811^{f} \\
\pm 0.671\end{array}$ \\
\hline \multicolumn{2}{|c|}{$\begin{array}{l}\text { Control (+ve) group fedon } \\
\text { (HFD) }\end{array}$} & $\begin{array}{l}18.788^{\dagger} \\
\pm 0.823\end{array}$ & $\begin{array}{l}115.810^{\mathrm{a}} \\
\pm 6.225\end{array}$ & $\begin{array}{l}15.986^{\mathrm{a}} \\
\pm 0.519\end{array}$ \\
\hline \multirow{4}{*}{ 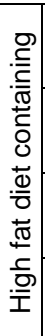 } & $\begin{array}{l}1.5 \% \text { dried un ripe } \\
\text { peel (DURSOP) }\end{array}$ & $\begin{array}{l}24.594^{\mathrm{e}} \\
\pm 1.338\end{array}$ & $\begin{array}{l}100.193^{b} \\
\pm 5.891\end{array}$ & $\begin{array}{l}14.183^{\mathrm{b}} \\
\pm 0.804\end{array}$ \\
\hline & $\begin{array}{l}\text { 3\%dried un ripe peel } \\
\text { (DURSOP) }\end{array}$ & $\begin{array}{l}32.167^{c} \\
\pm 0.983\end{array}$ & $\begin{array}{l}80.521^{d} \\
\pm 2.525\end{array}$ & $\begin{array}{l}12.316^{d} \\
\pm 0.493\end{array}$ \\
\hline & $\begin{array}{l}\text { 1.5\% dried rip peel } \\
\text { (DRSOP) }\end{array}$ & $\begin{array}{l}26.982^{d} \\
\pm 0.687\end{array}$ & $\begin{array}{l}89.784^{c} \\
\pm 2.356\end{array}$ & $\begin{array}{l}13.251^{\mathrm{c}} \\
\pm 0.864\end{array}$ \\
\hline & $\begin{array}{l}\text { 3\% dried ripe peel } \\
\text { (DRSOP) }\end{array}$ & $\begin{array}{l}34.939^{b} \\
\pm 0.563\end{array}$ & $\begin{array}{l}70.168^{\mathrm{e}} \\
\pm 1.565\end{array}$ & $\begin{array}{l}11.432^{\mathrm{e}} \\
\pm 0.577\end{array}$ \\
\hline
\end{tabular}

Values are expressed as means \pm SD.

Values at the same column with different letters are significant at $\mathrm{P}<0.05$. 
Egyptian J. of Nutrition Vol. XXXIV No. 3 (2019)

Table (3): Effect of sour orange peel on serum glucose, leptin and liver functions in albino rats fed on high fat diet:

\begin{tabular}{|c|c|c|c|c|c|c|}
\hline \multicolumn{2}{|c|}{$\mathrm{Z}$ parameter } & \multirow{2}{*}{$\begin{array}{l}\text { Glucose } \\
\mathrm{mg} / \mathrm{dl}\end{array}$} & \multirow[b]{2}{*}{$\begin{array}{l}\text { Leptin } \\
\mathrm{ng} / \mathrm{ml}\end{array}$} & \multicolumn{3}{|c|}{ Liver functions } \\
\hline \multicolumn{2}{|c|}{ Groups } & & & $\begin{array}{l}\text { AST } \\
U / L\end{array}$ & $\begin{array}{l}\mathrm{ALT} \\
\mathrm{U} / \mathrm{L}\end{array}$ & $\begin{array}{l}\text { ALP } \\
U / L\end{array}$ \\
\hline \multirow{2}{*}{\multicolumn{2}{|c|}{ Control (-ve) group }} & $77.830^{\mathrm{e}}$ & $5.986^{d}$ & $53.884^{\mathrm{e}}$ & $20.598^{\dagger}$ & $86.967^{d}$ \\
\hline & & \pm 4.508 & \pm 0.297 & \pm 2.749 & \pm 2.035 & \pm 1.966 \\
\hline \multirow{2}{*}{\multicolumn{2}{|c|}{ Control (+ve) group fedon (HFD) }} & $139.293^{a}$ & $17.925^{a}$ & $148.423^{a}$ & $78.476^{\mathrm{a}}$ & $168.487^{a}$ \\
\hline & & \pm 5.320 & \pm 1.474 & \pm 5.678 & \pm 2.392 & \pm 4.752 \\
\hline \multirow{8}{*}{ 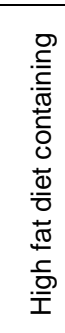 } & \multirow{2}{*}{$\begin{array}{r}1.5 \% \text { dried un ripe peel } \\
\text { (DURSOP) }\end{array}$} & $122.196^{b}$ & $14.594^{b}$ & $128.037^{b}$ & $68.341^{\mathrm{b}}$ & $147.749^{b}$ \\
\hline & & \pm 3.766 & \pm 1.774 & \pm 3.159 & \pm 3.503 & \pm 5.610 \\
\hline & \multirow{2}{*}{$\begin{array}{l}3 \% \text { dried un ripe peel } \\
\text { (DURSOP) }\end{array}$} & $102.381^{c}$ & $10.278^{c}$ & $112.369^{c}$ & $59.034^{d}$ & $137.158^{c}$ \\
\hline & & \pm 3.766 & \pm 1.364 & \pm 2.979 & \pm 2.308 & \pm 4.461 \\
\hline & \multirow{2}{*}{$\begin{array}{r}1.5 \% \text { dried rip peel } \\
\\
\end{array}$} & $124.193^{\mathrm{b}}$ & $15.024^{\mathrm{b}}$ & $126.777^{\mathrm{b}}$ & $65.005^{c}$ & $147.897^{b}$ \\
\hline & & \pm 2.556 & \pm 0.859 & \pm 1.009 & \pm 2.879 & \pm 3.005 \\
\hline & \multirow{2}{*}{$3 \%$ dried ripe peel (DRSOP) } & $95.732^{d}$ & $9.690^{c}$ & $105.364^{d}$ & $53.811^{\mathrm{e}}$ & $133.436^{c}$ \\
\hline & & \pm 4.537 & \pm 1.048 & \pm 4.114 & \pm 2.615 & \pm 2.150 \\
\hline
\end{tabular}

Values are expressed as means \pm SD.

Values at the same column with different letters are significant at $\mathrm{P}<0.05$

AST: Aspartate Amino Transferase

ALT: Alaine Amino Transferase

ALP: Alkaline phosphatas 


\section{Samar, K.H.; Seham A.M. Tharwat and Ashraf A. Abdel Megeid}

\section{References}

Alam , A , M ., Subban , N . andSarker , D . S . (2014).

Effect of citrus flavonoids, naringin and naringenim on metabolic dyndrom and their mechanism of action. Advances in nutrition : An International Review Journal ., (5) : 404 - 417.

Allain, C. Z.; Poon, L.S. and Chang, C.S. (1974).

Enzymatic determination of total serum cholesterol.Clin. chem., 20: 470-475.

Belfield, A. and Goldberg, D. M. (1971).

Normal Ranges and Diagnostic Value of Serum 5'Nucleotidase and Alkaline Phosphatase Activities in Infancy. Arch Dis Child ;46:842-846.

Campbell, J. A. (1963).

Methodology of protein vealuation, RGA nutria. Document $R$, 101 adds, 37, June meeting new york.

Claudia I.G.; Nuria, E. R.; Alberto,J. G.; Martha, R. M.; Blanca, D. V. and Rubén, F. G. (2015).

Plants with potential use on obesity and its complications.EXCLI J.; 14: 809-831. 
Egyptian J. of Nutrition Vol. XXXIV No. 3 (2019)

Foster, L.B. and Dumns, T.T. (1973).

Determination of triglycerides.J. Clin. Chem., 19:338-353.

Friedwald, W.T. ;Leng , R. R.J. and Fredrickson, D.S. (1972).

Estimation of concentration of low density lipoprotein separated by their different methods clin. Chem., 18: 499-502

Hegested, M.; Mill, R.S.; Elvhjem, G.A. and Hart, E.B. (1941).

Cholin in the nutrition of chicks.J. Biochem, 138- 459.

Karagozlu,M. Z.; Kim,M. and Lee,M. (2016).

Citrus peelethanol extract inhibits the adipogenesis caused from high fat diet, Food

Kelleya, D. S.; Adkinsa,Y. C.; ZuninoaS. J. and Breksa,A. P. (2015).

Citrus Limoninglucoside supplementation decreased biomaker of liver diease .J .of Functional Foods .,12 : 271 281.

Lee,Y .H .; Kim , Y . S .; Song , M .; Lee , M .; Park , J . P .andKim,H . (2015).

Aherba formula $\mathrm{H}$ To48, Citrus unshiu and Crataguspinnatifida, prevents obesity inhabiting adipogenesis and lipogenesis,Molecules. 20(6): 9656 - 9670. 


\section{Samar, K.H.; Seham A.M. Tharwat \\ and Ashraf A. Abdel Megeid}

Li, S.; Pan, M.H.; LO, C.Y. and HO, C.T. (2009).

Chemistry and health effects of polymethoxyflavones and hydroxylatedpolymethoxyllavones. J. of functional foods; (1): 2-12.

Lopes-Virella, M.F.; Stone, S.; Ellis, S. and Collwellm, J.A. (1977).

Cholesterol determination in high-density lipoproteins separated by three different methods.Clin. Chem., 23 (5): 882-893.

Reeves, P.G.; Bilson, F.H and Fahmy, Q. (1993).

Reported of the American institute of nutrition adholwriloing committee on the formulation of the Ain-76.A-Rodent diet. J. Nutri., 132:1939-1951.

Reitman, S. and Frankel, S. (1957).

Determination of glutamate pyruvate transferase.Am. J. Clin. Path., 28:56.

SAS, (2004).

Statistical analysis system, SAS users guide, statistics. SAS institute INC. Editors, Cart. And NC.

Schermer, S. (1967).

The blood morphology of laboratory animals long man and printed in great britaCreenand Co. LTD, 350 
Egyptian J. of Nutrition Vol. XXXIV No. 3 (2019)

Vozarova , B ., Stefan , N .; Lindsay, R . S .; Saremi , A.; Pratley, R . E .andBogardus, C. (2002).

High alanin aminotransferase is associated with decreased hepatic insulin sensitivity. Diabetes., 51 : 1889-1895 .

WHO (Corld health organization) (2015).

The WHO obesity report, Geneva, Switzerland.

WHO (world health origination) (2012) .

World wide obesity has nearly doubled since 1980. Global status. Report of WHO in on communicatble disease; Geneva. Switzerland.

Wu, T .; Tang . Q .; Zinchun , G.; Song , H .; Zheng , X. and Chen , W. (2013).

Bluebeery and Mullberry juice prevent obesity development in C5 78 I/ b mice. POLSONE , 8 (10) : 77 - 585. 


\section{Samar, K.H.; Seham A.M. Tharwat}

\section{and Ashraf A. Abdel Megeid}

التأثير المحتمل للتدعيم بقشور موالح البرتقال الحامضي على صورة الدهن ووظائف الكبد في فئران الالبينو التي تتغذى على غذاء عالي الدهون

\section{سمر كمال حسين* - أ.د. سهام عباس محمود ثروث* أدـ. أشرف عبد العزيز عبد المجيد**}

* طالبة دراسات عليا بقسم التغذية وعلوم الأطعمة ـ كلية الاقتصاد المنزلي جامعة حلوان ** قسم التظذية وعلوم الأطعمة ـ كلية الاقتصاد المنزلي - جامعة حلوان

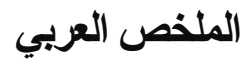

أجريت هذه الدراسة لمعرفة تأثير تدعيم الغذاء عالي الدهن بمستويين (1, 1 و ٪٪) من قشر البرتقال الحامضيالغير ناضج أو الناضج على مستوي الليتين والجلوكوز وصورة

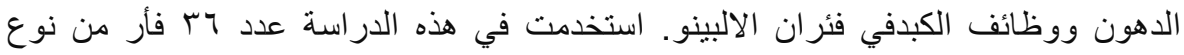

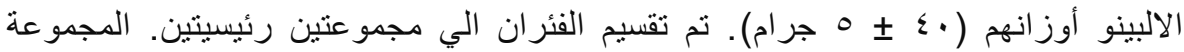

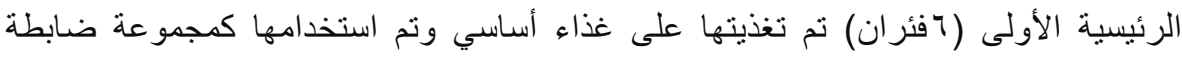
سالبة. المجموعة الرئيسية الثانية (•r فأر) تم تغذيتها على غذاء عالي الدهن، وتم تقسيمهم الداهي الي خمس مجموعات فرعية. المجموعة الفرعية الأولي تم تغذيتها على غذاء عالي الدهن طوال فترة التجربة وتم استخدامها كمجوعة ضابطة إيجابية. المجموعات الفرعية الأربع

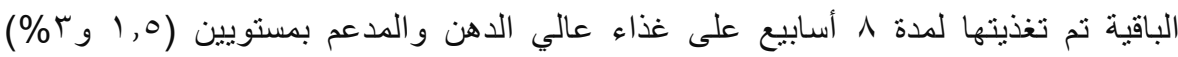
قشور برتقال حامضي مجف (ناضج وغير ناضج). في نهاية التجربة، نم نذدير الفئران وتم

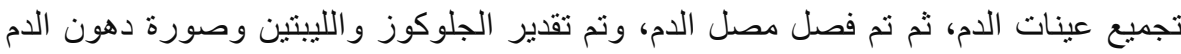
بالإضافة الي انزيمات الكبد المتضمن (AST, ALT and ALP). أشارت النتائج المتحصل 
Egyptian J. of Nutrition Vol. XXXIV No. 3 (2019)

عليها إلى أن تغذية فئران الالبينو التي تبلغ من العمر ب بوما على غذاء عالي الدهن و المدعم بمستوي (ץ\% قشتور برتقال حامضي مجفف غير ناضج أو ناضج) أحدثت تناقصا معنويا في مستوى الليبتين والجلوكوز و الكوليسترول و الجلسريدات الثناثية و الكوليسترول الليبوبروتينات منخفضة الكثافة و الكوليسترول الليبوبروتينات منخفضة الكثافة جدا ومستويات انزيمات الكبد (AST, ALT and ALP) ، وون ناحية اخري حدث نزايدا معنويا في مستوى كوليسترول الليبوبروتينات عالية الكثافة في فئران الالبيوا التي تغذت ونت علي غذاء عالي الدهن و المدعم بمستوى ٪\% قشور برتقال حامضي مجفف (ناضج وغير ناضج)،

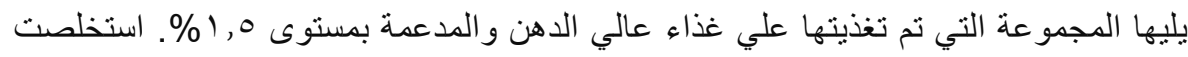
النتائج أن تناول الفئر ان غذاء عالي الدهن المدعم بقشور البرتقال الحامضي المجفف (الغير عندي ناضج و الناضج) بالمستويين (r\% أو 0, 1\%) يمكن ان بساعد في التحكم في السمنة ومضاعفاتها. 